\title{
Soft Power Construction of University Culture
}

\author{
Li-bin Zhou \\ Academy of Social Sciences \\ Northeastern University at Qinhuangdao \\ Qinhuangdao, China \\ zhoulibin50@aliyun.com
}

\author{
He Wang \\ Academy of Social Sciences \\ Northeastern University \\ Shenyang, China
}

\begin{abstract}
The connotation of the soft power of university culture is the influence of the culture and value advocated by the university on cultural literacy and moral level of teachers and students and the whole society. The construction of the soft power of the university culture includes three levels, which are concept, security and environment, and follow these principles: (1) Harmonious principle; (2) The core value system principle; (3) The principle of the join of the overall planning and step-by-step implementation; (4) The principle of the fusion of scientific spirit and humanistic spirit; (5) Innovation principle.
\end{abstract}

\section{Keywords-university culture; soft power; construction}

\section{I . INTRODUCTION}

The international core competence of a country mainly has two aspects. One is hard power, and the other is soft power. Hard power is economic, military and technological strength of a country, and the soft power is cultural influence of a country. The soft power of a country includes the attractiveness of ideology and political value, the appeal of national spirit and social culture, the ability of political mobilization, the ability of operating international organization, and so on. The building of soft power of college culture is important for a country to build soft power. College culture has functions of innovation, guidance, demonstration, radiation and transmission, and becomes engine of national culture soft power by cultivating talents, creating knowledge and more and more direct social services.

Internationally, the more famous universities, the stronger cultural soft power. After all, soft power is a kind of competitive power, and the cultural soft power of college is a kind of core competitiveness, which is mainly embodied with influence, attraction and competitiveness of cultural individuality. The education aim of Harvard University is veritas, which makes it always lead the development trend of American higher education. Stanford University takes 'higher education is a public service' as its educational idea, which makes it become a milestone in the history of American education. On the 250th anniversary of Yale University foundation, Time weekly wrote about that Yale University had been always insisting on conservatism in the best and the most real sense since it was founded. The educational idea of University of Pennsylvania is taking in whatever beneficial, innovation and application, which is the basis for University of Pennsylvania to be in an invulnerable position in the educational history of America.

Looking from China, under the background of constructing innovative country, high schools who undertake the important task of invigorating the nation through science and education and strengthening the country through talents have already went from ivory tower to social center. The high schools of '211 project' and '985 project' go up to a road of rapid development through the financial support of country, province and city. And through consolidation and expansion, the strength of some high schools is also greatly enhanced. Under these circumstances, high schools are faced with the competitions of existence and development. Therefore, it is urgent for China's high schools to construct cultural soft power.

\section{II . CONNOTATION OF SOFT POWER OF UNIVERSITY CULTURE}

The connotation of soft power of university culture is decided by the nature of university. In essence, the university is not only a place for imparting knowledge, but a place of cultural moralization and cultural enlightenment.

The culture moralization and cultural enlightenment of university reflects in following two aspects. (1) The high school takes academic culture and moral culture as its starting points, and gradually forms distinctive academic tradition, values and campus culture through the system, rules, etiquette, management, community, sports, art, teaching, scientific research, campus environment, and so on. Simultaneity behavior, temperament and idea with universal meaning are presented on management's thinking way, learning attitude, running measure of a school as well as teacher, student and staff themselves, which becomes school spirit and study style that different from the others. (2) Through many forms such as cultivating high level specialists and producing spiritual products, high schools cultivate constructors and high-quality talents for the society, transport advanced idea to the society, and provide intellectual support, technology support and knowledge contribution for enhancing the nation's competitiveness. In high schools cultures, scientific spirit, humanistic tradition, innovation consciousness, elegant entertainment and so on have radiation and influence on outside society, and make distinctive contributions for the construction of social culture.

Combining the characteristic of university culture and the understanding of soft power by Joseph S. Nye (i.e. the ability for attraction and persuasion to acquire better results ) with the attribute of high schools culture, the connotation of high schools culture can be understood as the influence of 
culture and values advocated by high schools on cultural quality and morality level of teachers, students, and the whole society.

\section{PRINCIPLE OF SOFT POWER CONSTRUCTION OF UNIVERSITY CULTURE}

The principle is to reflect the nature of the objective laws of the development and change of things, and is the code of conduct that must be followed in promoting the construction and performing the work. The construction of university culture soft power, has its own law of development, and also has some of the principles that must be followed. The college cultural soft power construction which guided by the competitiveness should follow the following principles.

First, it is the principle of harmony. College is the palace of the harmoniously cultural inheritance. Under the influence of harmonious culture, high school students are conducive to cultivate good manners and shape the noble soul, and improve the comprehensive quality. Harmonious culture has a guide role for college students to form a correct outlook on life, values and world view, a good ideology and morality, a good mental status, a noble personality behavior, and so on. Moreover, colleges and universities are an important part of social harmony culture, and have special effects on serving and leading social culture in the construction of harmonious culture. The successful construction of college culture of harmony would be beneficial to lead the community to form a common ideals and beliefs and ethics. And it also makes the advocating harmony and maintaining harmony become a common pursuit of the whole society.

Second, it is the principle of core value system. "The decision of the CPC Central Committee on building a socialist harmonious society on major issues" clearly definite the guiding ideology of Marxism, the common ideal of socialism with Chinese characteristics, the national spirit with patriotism as the core and spirit of the times with reform and innovation as the core, the socialist concept of honor and dishonor as the basic content of the socialist core value system. "Decision" first proposed the strategic task of building a socialist core value system, and clarified the meaning of the socialist core value system and its necessary connection with the building of a harmonious culture; deepened the understanding of the essence of socialism with Chinese characteristics, reflected the era requirements and achieved the major theoretical innovation. The field of higher education which shoulders the important task of teaching and educating should consciously accept the norms of the socialist core value system. As university administrators, must be fully and accurately understand the profound meaning of the socialist core value system, firmly grasp the direction of the construction of the cultural soft power, pay attention to the dominant and leading of socialist core value system, especially in this age of active thinking, ideas clashing and diverse cultures integrating, lead and integrate diverse ideology and social thought through socialist core values with broad appeal and cohesion to make advanced culture be flourished in colleges and universities and healthy culture be shared by the majority of teachers and students.
Third, it is the principle of cohesion of the overall planning and step-by-step implementation. College cultural soft power construction is necessary to carry out long-term planning and whole overall arrangement, and to propose long-term goals and general requirements, and again to the short-term goal, safeguard mechanism of task decomposition, the implementation of responsibility, present a set of measures and implementation procedures to ensure that college cultural soft power construction will be of key prominent, interlocking, step by step, the overall advancement.

Fourth, it is the principle of the integration of scientific spirit and humanistic spirit. The college cultural soft power is necessary to vigorously advocate looking for the truth and being practical, pioneering and innovative spirit of science, and fostering a style of study that teachers and students seek truth from facts, but also attaches great importance to the people-oriented, and to promote the comprehensive development of the human spirit nurture and the unity of Science Education and Humanities Education, to nurture teachers and students an elegant aesthetic taste.

Fifth, it is the principle of innovation. University administrators' cultural self-consciousness, as required by the report of the 17th, "promoting the Chinese culture," "a comprehensive understanding of the traditional culture of the motherland", and vigorously promote the excellent cultural heritage, at the same time with an open mind, consciously "absorb all outstanding civilization achievement", drawing high-quality cultural resources of the various ethnic groups, and attaching great importance to the heritage and reference on the basis of actively promoting cultural innovation, enhancing the vitality of cultural development of colleges and universities, and playing a unique role to "build the common spiritual home for the Chinese nation", enhancing the cultural "soft power" and "international influence".

\section{IV . CONSTRUCTION PATHS OF SOFT POWER OF UNIVERSITY CULTURE}

The soft power of university cultural is not frozen, but like gas. It can put the "soft" soul- value concept to the scientific research, teaching, management, service in every aspect, being reflected in the teachers and students of the value concept of recognition and performing, embodied in the social public good appraisal of University culture. University culture is personality education culture which created for the realization of the education nature; it's the mode of value identity, spiritual pursuit and behavior of all staffs. Therefore, soft power construction of university culture needs to cultivate students by the entire campus cultural atmosphere and the humanistic spirit of traditional education.

And this requires all levels of leadership, teachers, administrators and students to build the school unique cultural spirit and cultural atmosphere which fusion of history tradition and spirit of the times, thus enhance cultural quality of university education to soft power construction of university culture. It's obvious a higher level

Specifically, the construction of soft power of university culture includes three hierarchies. The first is concept layer, 
namely value orientation of the school, which often condenses into motto for guideline. The second is security layer, which is the system to realize value orientation of university. The third is presentation layer, namely the show of various types. Usually, campus culture mainly refers to the show of cultural image.

The relationship of the three layers is shown in fig. 1 .

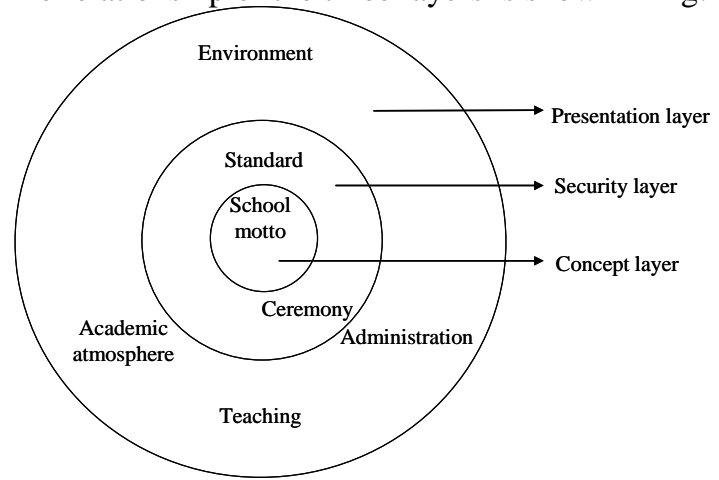

Figure 1. Hierarchy of soft power construction of university culture.

\section{A. Concept of Soft Power Cconstruction: School Motto}

The school motto is basic code of conduct and ethics for teachers and students. It's not only the reflection of the idea of running a school and school spirit, but also an important content of the construction of campus culture, so it's the concentrated expression of a school's teaching, learning and school spirit. At the same time, school motto reflects the core contents of cultural spirit. Therefore, motto is the concept of layer construction of university culture soft power. Some famous domestic and foreign universities not only are admired in terms of scientific and technological achievements, academic reputation, creating excellence but also its unique and brilliant motto. The Humboldt University of Berlin carved Marx's famous "the philosophers have only interpreted the world in various ways, but the problem is to change the world" in the teaching building hall mouth as a motto; the United States West Point is the cradle of army officers, it use "duty, honor, country" (be engraved on the square wall) as the motto; California colleges and universities, the emblem engraved on "let there be light shine" (LET THERE BE LIGHT); etc. In China, Tsinghai University's motto is "unremitting self-improvement, social commitment", Southeast University aims at "absolute perfection". All of those have put into students' minds, and practiced in learning, life and work.

The college's motto not only influenced the formation of campus culture, teaching style and studying style, guiding teachers and students' behavior, leading the development direction of school functions, its propagation but also benefited to the formation of healthy personality and construction of social. And Graduates will spread the spirit to society, what affects the cultivation and formation of the national character, thereby promoting social development.

\section{B. Protection Layer of The Soft Strength Construction: Rules and Etiquette}

The system construction is the important basis to normal operation of university, without system construction, it is difficult to imagine for any a university. Therefore, in the system construction of universities, university management is the most important task, and all the managers should pay attention to. When the system is manifested in the form of rules, it must reflect the values of the culture, the cultural spirit, cultural philosophy. But when the culture is regular, it must adopt the specification or the form of etiquette. In a sense, there is no cultural value system, there is no institutional forms of culture. Therefore, rules and etiquette is the construction of University's protection of cultural soft power, rules and etiquette to establish in the concept which mutual support by all school staff and students, to rely on the majority of the staff and students to develop, maintain and implement. More importantly, it needs to turn the rules and regulations of the school into the consciousness and habits of teachers, students and employee.

Through the construction of rules and etiquette, it cultivates consciously normative behavior of the people and good manners, more importantly, gradually forming a kind of common value orientation, a kind of the righteousness and a harmonious campus atmosphere in the process. Consequently, a university will has its own good style of study, teaching style and school spirit as time goes by, and then lays a solid foundation for the cultural construction of colleges and universities. In a sense, only when laying a solid foundation for the foundation of system culture construction can have the resplendent top design of college culture construction.

\section{Presentation Layer of Soft Power Construction:} Academic, Teaching, Management and Environment

The academic culture, teaching culture, management culture and environmental culture are an important part of college cultural construction of soft power, and also an important manifestation of the cultural soft power.

1) Soft Power of Academic Culture:Soft power of academic culture contains two meanings, namely, academic and atmosphere. Academic, refers to specialized systematic knowledge, and atmosphere, is a kind of spirit. The academic atmosphere, broadly, refers to an environment and atmosphere of academic research. A lively academic atmosphere is not only shown in regular academic seminars, lectures, academic forum and other academic activities, but also in the variously informal occasions such as chat, parties, and so on. Specifically, the academic atmosphere is the intellectual community's preference and love based on academic exploration and innovation, their arguments and discussion of advocating different academic point of view and forming different schools in a variety of scientific research, and a pursuit and atmosphere of expanding the depth and breadth of scientific research.

2) Soft Power of Teaching Culture:The fundamental task of universities is to cultivate talents, and the teaching work is 
the central work of the school. Classroom teaching is the main body and the foundation of higher education. That grasps the classroom teaching is the key to improve the quality of the whole higher education as well as the important manifestation of the cultural soft power. Because, regardless of the rise and fall of great powers or personal victory or defeat, eventually depending on their learning level. In universities, the main way of student learning is in the classroom.

3) Soft Power of Management Culture:The management of cultural soft power is a modern university personality as well as a manifestation of modern university core competitiveness, including cohesion, education, creativity and influence. With this basis modern universities can survive, develop, run schools and bear significant social responsibility.

Show by the dissipative structure theory: internal and external system to reach a new balance only by continuously exchange energy. Any organizational unit's development depends mainly on its internal organization, namely, interpersonal relationship inside, so keeping a good and harmonious interpersonal relationship is an important factor to ensure the development potential of the organization. This kind of interpersonal relationship involves initially the relationship between school administrators and teachers. Practice of the university management shows that the management efficiency can be enlarged if school leaders and teachers are harmonious and cooperative. Conversely, it is not conducive to the management of universities.

Therefore, university management must follow the principle of people-oriented, and create university management culture with contemporary atmosphere and its own characteristics.

4) Soft Power of Environmental Culture:Soft power of environmental culture in universities includes physical environment and psychological environment. Physical environment refers to natural landscape such as buildings, facilities, campus flowers and trees, and psychological environment refers to humanistic factors such as the human environment, school spirit, style of teaching and various cultural and art atmosphere. Most of international famous universities have paid great attention to the environmental culture. For example, the main tone of Harvard University campus is "Harvard red", Oxford university campus have maintained a delicate greensward for 800 years, and students held the boat race on the Thames River in May every year, which set up famous brand for the school, and become a kind of spirit.

\section{CONCLUSION}

The above is only a preliminary exploration of our results. It's also need to be tested in practice if these results have promotion and application or not. Fundamentally speaking, the construction of cultural soft power is not only a theoretical problem, but also a practical problem. It does not have a fixed pattern. Researchers must have a basis in reality, strengthen exchanges and cooperation with other colleges and universities, learn from each other, commit to reform, and continuously innovate, gradually finding out a set of perfect model.

\section{REFERENCES}

[1] Joseph S. Nye, Hard Power and Soft Power, Beijing: Beijing University Press, 2005.

[2] Joseph S. Nye and Jr., "Soft power," Foreign Policy, No. 80, Twentieth Anniversary (Autumn, 1990).

[3] Robert.O.Keohane and Joseph S. Nye, Power and Interdependence, Beijing: Beijing University Press, 2002.

[4] Zhongying Pang, "The connotation of China's soft power," Outlook Weekly News, vol.45, Nov. 2005, pp.62.

[5] Futing Gao, "Strengthen its study is the important measure to enhance the soft power of culture," Beijing Education (Higher Education), vol. 5, May 2010, pp. 41-43. 